\title{
Hubungan Profil Lipid dan HbA1C dengan Kadar Alanin Aminotransferase pada Pasien Diabetes Melitus Tipe 2
}

\author{
${ }^{1}$ Fitriyanti Patulak \\ ${ }^{2}$ Karel Pandelaki \\ ${ }^{2}$ Bradley J. Waleleng
}
${ }^{1}$ Program Studi Pendidikan Dokter Fakultas Kedokteran Universitas Sam Ratulangi Manado
${ }^{2}$ Bagian Ilmu Penyakit Dalam Fakultas Kedokteran Universitas Sam Ratulangi Manado Email: fitriyantipatulak@gmail.com

\begin{abstract}
Elevated $\mathrm{HbA1C}$ in patients with T2DM will increases the risk of complications. Dyslipidemia is a common comorbidity in patients with T2DM. Uncontrolled T2DM patients and dyslipidemia have a high risk of chronic complications such as non alcoholic fatty liver disease (NAFLD) that causes liver cell damage. Alanine aminotransferase (ALT) test is typically used to detect liver cell damage. This study was aimed to obtain the relationship between lipid profile and HbA1c and ALT among T2DM patients at Prof. Dr. R. D. Kandou Hospital Manado. This was a descriptive and analytical study with a cross sectional design using secondary data of T2DM patients at the Endocrine Polyclinic of Prof. R. D. Kandou Hospital Manado from January to September 2019. The results of the Spearman rank correlation test were, as follows: correlation between ALT and total cholesterol levels with $\mathrm{p}=0.625$ and $\mathrm{r}=-0.080$; correlation between ALT and HDL levels with $\mathrm{p}=0.302$ and $\mathrm{r}=-0.167$; correlation between ALT and LDL levels with $\mathrm{p}=0.625$ and $\mathrm{r}=-0.080$; correlation between ALT and triglyceride levels with $\mathrm{p}=0.964$ and $\mathrm{r}=-0.007$; and correlation between ALT and $\mathrm{HbA} 1 \mathrm{c}$ levels with $\mathrm{p}=0.237$ and $\mathrm{r}=-0.191$. In conclusion, there were no significant relationships between lipid profile and HbA1c levels and ALT.
\end{abstract}

Keywords: T2DM, HbA1c, ALT, lipid profile

\begin{abstract}
Abstrak: Peningkatan HbA1c pada pasien diabetes melitus tipe 2 (DMT2) akan meningkatkan terjadinya risiko komplikasi. Dislipidemia merupakan komorbid yang umum ditemukan pada pasien DMT2. Penderita DMT2 yang tidak terkontrol disertai dislipidemia memiliki risiko tinggi untuk mendapatkan komplikasi kronik seperti non alcoholic fatty liver disease (NAFLD) yang mengakibatkan kerusakan sel hati. Pemeriksaan laboratorium yang sering dilakukan untuk melihat adanya kerusakan pada sel hati yaitu alanin aminotransferase (ALT). Penelitian ini bertujuan untuk mengetahui hubungan antara profil lipid dan HbA1c dengan kadar ALT pada pasien DMT2 di RSUP Prof. Dr. R. D. Kandou Manado. Jenis penelitian ialah deskriptif analitik dengan desain potong lintang menggunakan data sekunder pasien DMT2 yang datang berobat ke Poliklinik Endokrin RSUP Prof. Dr. R. D. Kandou pada bulan Januari-September 2019. Hasil uji korelasi Spearman rank menunjukkan nilai hubungan antara ALT dan kolesterol total kadar $\mathrm{p}=0,625$ dan $\mathrm{r}=-0,080$; nilai hubungan antara ALT dan kadar HDL $\mathrm{p}=0,302$ dan $\mathrm{r}=-0,167$; nilai hubungan antara ALT dan kadar LDL $\mathrm{p}=0,625$ dan $\mathrm{r}=-$ 0,080; nilai hubungan antara ALT dan kadar trigliserida $\mathrm{p}=0,964$ dan $\mathrm{r}=-0,007$; serta nilai hubungan antara ALT dan kadar HbA1C $\mathrm{p}=0,237$ dan $\mathrm{r}=-0,191$. Simpulan penelitian ini ialah tidak terdapat hubungan antara profil lipid dan HbA1c dengan kadar ALT.
\end{abstract}

Kata kunci: diabetes melitus tipe 2, HbA1c, ALT, profil lipid 
Diabetes melitus kini menjadi ancaman serius kesehatan global akibat perubahan gaya hidup yang tidak sehat. Diabetes melitus (DM) merupakan suatu penyakit metabolik kronis ditandai dengan adanya peningkatan kadar glukosa dalam darah (hiperglikemia) yang diakibatkan oleh gangguan sekresi insulin oleh sel $\beta$ pankreas, kerja insulin, atau keduanya. ${ }^{1}$ Diabetes berada di peringkat ketujuh sebagai 10 penyakit penyebab kematian di dunia, dimana 90\%-95\% kasus merupakan DM tipe 2 (DMT2). ${ }^{2,3}$

International Diabetes Federation (IDF) memperkirakan Indonesia berada di peringkat ke-6 dengan jumlah penderita diabetes yang berusia 20-79 tahun sekitar 10,3 juta orang pada tahun 2017, dan diperkirakan meningkat menjadi 16,7 juta orang pada tahun 2045. ${ }^{4}$ Meningkatnya prevalensi DM kemungkinan terjadi karena perkembangan ekonomi, urbanisasi yang tidak terkendali, perubahan gaya hidup dan konsumsi makanan yang tidak sehat, serta peningkatan pelayanan kesehatan sehingga usia pasien DM menjadi lebih panjang. Sulawesi Utara berada di urutan keempat sebagai provinsi dengan prevalensi DM tertinggi di Indonesia. ${ }^{6}$

Diabetes dikatakan terkendali dengan baik apabila kadar lipid dan HbA1c sesuai dengan kadar yang diharapkan. ${ }^{7}$ Hemoglobin terglikosilasi (HbA1c) digunakan sebagai salah satu parameter kontrol gula darah. Peningkatan HbAlc pada pasien DM akan meningkatkan terjadinya risiko komplikasi. $^{8}$

Kelainan komorbid yang sering ditemukan pada DMT2 ialah dislipidemia. Dislipidemia merupakan kelainan metabolisme lipid ditandai dengan adanya peningkatan maupun penurunan fraksi lipid dalam plasma. ${ }^{9}$ Untuk mengetahui kadar lipid pada penderita DMT2 perlu dilakukan pemeriksaan profil lipid. $^{7}$

Diabetes yang tidak terkendali berisiko terjadi komplikasi kronis, baik mikrovaskular maupun makrovaskular. ${ }^{10}$ Selain itu penyandang DM yang disertai dislipidemia juga memiliki risiko tinggi untuk mendapatkan komplikasi kronik seperti non alcoholic fatty liver disease (NAFLD). ${ }^{2}$ Pemeriksaan laboratorium, USG, maupun biopsi hati dapat dilakukan untuk mendiagnosis NAFLD. Salah satu pemeriksaan laboratorium yang sering dilakukan untuk melihat adanya kerusakan sel hati yaitu alanin aminotransferase (ALT). ${ }^{11}$

Berdasarkan latar belakang ini, maka peneliti ingin mengetahui hubungan antara profil lipid dan $\mathrm{HbA} 1 \mathrm{c}$ dengan kadar alanin aminotransferase pada pasien DMT2 di Poliklinik Endokrin Penyakit Dalam RSUP. Prof. Dr. R. D. Kandou Manado.

\section{METODE PENELITIAN}

Penelitian ini menggunakan data sekunder pasien DMT2 yang datang berobat di Poliklinik Endokrin Penyakit Dalam RSUP Prof. Dr. R. D. Kandou Manado periode Januari - September 2019. Jenis penelitian ini ialah deskriptif analitik dengan desain potong lintang.

Populasi penelitian mencakup seluruh pasien DMT2 yang datang berobat di Poliklinik Endokrin periode Januari-September 2019 sedangkan sampel penelitian ini mencakup semua pasien DMT2 yang memiliki data pemeriksaan profil lipid, $\mathrm{HbA} 1 \mathrm{C} \geq 7 \%$, dan alanin aminotransferase. Pada penelitian ini digunakan uji korelasi Spearman rank untuk mengetahui hubungan antara variabel penelitian.

\section{HASIL PENELITIAN}

Penelitian ini dilaksanakan di Instalasi Rekam Medik RSUP Prof. Dr. R. D. Kandou Manado. Sampel pasien DMT2 yang memenuhi kriteria inklusi berjumlah 40 orang yang terdiri atas 19 laki-laki $(47,5 \%)$ dan 21 perempuan $(53,5 \%)$. Pada penelitian ini didapatkan usia pasien bervariasi mulai dari 31 tahun hingga 80 tahun, dengan rerata 52,63 tahun.

Tabel 1 menunjukkan kisaran nilai tertinggi dan terendah serta nilai rerata dari kadar kolesterol total, kadar kolesterol HDL, kadar kolesterol LDL, kadar trigliserida, kadar HbA1c, dan kadar ALT. 
Tabel 1. Karakteristik variabel penelitian

\begin{tabular}{lccccc}
\hline \multicolumn{1}{c}{ Variabel } & N & Min & Maks & Rerata & Distribusi \\
\hline Jenis kelamin & & & & & \\
$\quad$ Laki-laki & 19 & & & & \\
$\quad$ Perempuan & 21 & & & & \\
Usia (tahun) & 40 & 31 & 80 & 52,63 & \\
Kolesterol total (mg/dL) & 40 & 101 & 299 & 197,70 & 0,560 \\
Kolesterol HDL (mg/dL) & 40 & 25 & 68 & 42,18 & 0,040 \\
Kolesterol LDL (mg/dL) & 40 & 39 & 221 & 121,08 & 0,839 \\
Trigliserida (mg/dL) & 40 & 57 & 496 & 172,18 & 0,000 \\
HbA1C (\%) & 40 & 7,0 & 14,1 & 10,14 & 0,211 \\
ALT (U/L) & 40 & 9 & 71 & 21,25 & 0,000 \\
\hline
\end{tabular}

Hasil uji normalitas yang dilakukan menggunakan Shapiro-Wilk dan didapatkan variabel yang terdistribusi normal ( $\mathrm{p}$ $>0,05)$ yaitu kadar kolesterol total, kadar kolesterol LDL, dan kadar HbA1c sedangkan kadar kolesterol HDL, kadar trigliserida, dan kadar ALT tidak terdistribusi normal. Oleh karena beberapa variabel tidak terdistribusi normal maka untuk mengetahui hubungan antara profil lipid dan HbA1c dengan kadar ALT digunakan analisis bivariat yaitu uji korelasi Spearman rank.

Hasil analisis hubungan kadar ALT dengan kadar kolesterol total memperoleh nilai $p=0,625(\alpha=0,05)$ yang menunjukkan tidak terdapat hubungan bermakna antara kadar ALT dan kadar kolesterol total. Nilai korelasi data yang diperoleh sebesar 0,080 yang menunjukkan korelasi antara kadar ALT dan kadar kolesterol total sangat lemah dan bernilai negatif.

Hasil analisis hubungan kadar ALT dengan kadar kolesterol HDL memperoleh nilai $p=0,302(\alpha=0,05)$ yang menunjukkan tidak terdapat hubungan bermakna antara kadar ALT dan kadar kolesterol HDL. Nilai korelasi data yang diperoleh sebesar 0,167 yang menunjukkan korelasi antara kadar ALT dan kadar HDL sangat lemah dan bernilai negatif.

Hasil analisis hubungan kadar ALT dengan kadar kolesterol LDL memperoleh nilai $\mathrm{p}=0,625(\alpha=0,05)$ yang menunjukkan tidak terdapat hubungan bermakna antara kadar ALT dan kadar kolesterol LDL. Nilai korelasi data yang diperoleh sebesar 0,080 yang menunjukkan korelasi antara kadar ALT dan kadar LDL sangat lemah dan bernilai negatif.

Hasil analisis hubungan kadar ALT dengan kadar trigliserida memperoleh nilai $p=0,964(\alpha=0,05)$ yang menunjukkan tidak terdapat hubungan bermakna antara kadar ALT dan kadar trigliserida. Nilai korelasi data yang diperoleh sebesar 0,007 yang menunjukkan korelasi antara kadar ALT dan kadar trigliserida sangat lemah dan bernilai negatif.

Hasil analisis hubungan kadar ALT dengan kadar HbA1c memperoleh nilai $p=0,237(\alpha=0,05)$ yang menunjukkan tidak terdapat hubungan bermakna antara kadar ALT dan kadar HbA1c. Nilai korelasi data yang diperoleh sebesar 0,191 yang menunjukkan hubungan antara kadar ALT dan kadar HbA1C sangat lemah dan bernilai negatif.

\section{BAHASAN}

Hasil analisis hubungan yang dilakukan antara kadar ALT dengan kadar kolesterol total, kadar kolesterol HDL, kadar kolesterol LDL, dan kadar trigliserida menggunakan uji korelasi Spearman rank, menunjukkan bahwa tidak terdapat hubungan bermakna dan nilai korelasi yang menunjukkan hubungan yang negatif. Hasil penelitian ini sejalan dengan penelitian yang dilakukan di Arab Saudi oleh 
Alzahrani et al ${ }^{12}$ yang menyatakan bahwa tidak terdapat hubungan bermakna antara peningkatan kadar ALT dengan kadar kolesterol total, HDL, LDL, dan trigliserida. Berbeda halnya dengan penelitian yang dilakukan oleh Al-Jameil et al $^{13}$ yang menunjukkan adanya hubungan positif yang bermakna antara peningkatan kadar ALT dengan kadar kolesterol total, LDL, dan trigliserida. Selain itu, beberapa peneliti juga melaporkan adanya hubungan bermakna antara peningkatan kadar ALT dengan kadar kolesterol total dan trigliserida, tetapi tidak terdapat hubungan dengan kadar LDL dan HDL. ${ }^{14,15}$

Hasil analisis hubungan antara kadar ALT dengan kadar HbA1c menunjukkan bahwa tidak terdapat hubungan bermakna dengan nilai korelasi yang negatif. Hal ini sejalan dengan penelitian Saligram et $\mathrm{al}^{15}$ terhadap pasien DM tipe 2 yang baru terdiagnosis yang menunjukkan bahwa tidak terdapat hubungan bermakna antara kadar ALT dengan kadar HbA1C. Hasil penelitian ini juga sejalan dengan penelitian oleh Alzahrani et al ${ }^{12}$ yang menyatakan bahwa tidak terdapat hubungan antara peningkatan kadar ALT dengan kadar HbA1c, namun hasil penelitian ini bertolak belakang dengan penelitian yang dilakukan oleh Shahwan et al $^{14}$ yang menyimpulkan adanya hubungan antara peningkatan kadar ALT pada pasien dengan kadar $\mathrm{HbAlc}$ $\geq 7 \%$.

Pasien DMT2 yang disertai dislipidemia berisiko tinggi untuk mendapatkan komplikasi kronik yaitu NAFLD. ${ }^{2}$ Peningkatan ALT pada pasien DMT2 menunjukkan adanya NAFLD. Selain itu, kondisi hiperglikemia yang tidak terkontrol (HbA1c $\geq 7 \%$ ) dapat mengakibatkan peningkatan stress oksidatif yang ditandai oleh adanya peningkatan reactive oxygen species (ROS) dalam jaringan yang mengarah pada peningkatan peroksidasi lipid yang mengakibatkan cedera hepatosit dan berakibat pada kematian sel (nekrosis atau apoptosis).

Hiperglikemia dan resistensi insulin memiliki korelasi penting sehubungan dengan diabetes dan gangguan hati.
Dilaporkan bahwa individu dengan $\mathrm{HbA1c}$ tinggi memiliki risiko steatosis hati yang lebih tinggi. ${ }^{14,16} \mathrm{Hal}$ ini belum dapat dibuktikan dengan hasil penelitian ini.

Perbedaan yang diperoleh antara hasil penelitian ini dengan penelitian-penelitian sebelumnya dapat dipengaruhi oleh perbedaan jumlah sampel, metode penelitian, maupun karakteristik dari sampel penelitian yang dapat menyebabkan inkonsistensi pada hasil penelitian.

Dalam penelitian ini, data yang digunakan hanya berdasarkan data sekunder sehingga tidak dapat dilakukan wawancara yang lebih lanjut tentang kebiasaan berolahraga maupun pengobatan sebelumnya yang dapat memengaruhi variabel penelitian. Keterbatasan dalam penelitian ini juga tidak memperhitungkan faktorfaktor lain yang kemungkinan dapat berpengaruh seperti lama menderita diabetes dan lama pengobatan yang telah dilakukan.

\section{SIMPULAN}

Berdasrkan hasil penelitian ini dapat disimpulkan bahwa tidak terdapat hubungan bermakna antara kadar kolesterol total, HDL, LDL, trigliserida dan HbA1C dengan kadar ALT pada pasien DM tipe 2 di Poliklinik Endokrin Penyakit Dalam RSUP. Prof. Dr. R. D. Kandou Manado.

Untuk penelitian selanjutnya disarankan untuk menggunakan data primer pada kasus DM tipe 2. Selain itu, dapat dilakukan penelitian lanjut dengan menggunakan jumlah sampel pasien DM tipe 2 yang lebih besar dengan metode penelitian yang berbeda.

\section{DAFTAR PUSTAKA}

1. Purnamasari D. Diagnosis dan klasifikasi diabetes melitus. In: Setiati S, Alwi I, Sudoyo AW, Simadibrata M, Setiyohadi B, Syam AF, editors. Buku Ajar Ilmu Penyakit Dalam (6th ed). Jakarta: Interna Publishing, 2014; p. 2325-9.

2. World Health Organization.. Classification of diabetes mellitus. Geneva: WHO, 2019.

3. World Health Organization. The top 10 causes of death. 2018 May 24 [cited 2019 Aug 21]. Available from: https://www.who. 
int/ news-room/fact-sheets/detail/thetop-10-causes-of-death.

4. IDF Diabetes Atlas (8th ed). Brussels: International Diabetes Federation, 2017.

5. Suyono S. Diabetes melitus di Indonesia. In: Setiati S, Alwi I, Sudoyo AW, Simadibrata M, Setiyohadi B, Syam AF, editors. Buku Ajar Ilmu Penyakit Dalam (6th ed). Jakarta: Interna Publishing, 2014; p. 2318-21.

6. Riset Kesehatan Dasar (RISKESDAS). Jakarta: Litbangkes, 2018.

7. PERKENI. Kosensus Pengelolaan dan Pencegahan Diabetes Melitus Tipe 2 di Indonesia. Jakarta: PERKENI, 2015.

8. Gahung RY, Pandelaki K, Moeis ES. Hubungan kadar HbA1C dengan estimasi filtrasi glomerulus pada pasien DM tipe 2. e-CliniC. 2016;4(1).

9. PERKENI. Panduan Pengelolaan Dislipidemia di Indonesia. Jakarta: PERKENI, 2015.

10. Waspadji S. Komplikasi kronik diabetes: mekanisme terjadinya, diagnosis, dan strategi pengelolaan. In: Setiati S, Alwi I, Sudoyo AW, Simadibrata M, Setiyohadi B, Syam AF, editors. Buku Ajar Ilmu Penyakit Dalam (6th ed). Jakarta: Interna Publishing, 2014; p. 2361-2.

11. Hasan I. Perlemakan hati non alkoholik. In: Setiati S, Alwi I, Sudoyo AW, Simadibrata M, Setiyohadi B, Syam
AF, editors. Buku Ajar Ilmu Penyakit Dalam (6th ed). Jakarta: Interna Publishing, 2014; p. 2002-4.

12. Alzahrani SH, Baig M, Bashawri JI, Aashi MM, Shaibi FK, Alqarni DA. Prevalence and association of elevated liver transaminases in type 2 diabetes mellitus patients in Jeddah, Saudi Arabia. Cureus. 2019;11(7):1-8.

13. Al-Jameil N, Khan FA, Arjumand S, Khan MF, Tabassum H. Associated liver enzyms with hyperlipidemic profil in type 2 diabetes patients. Int J Clin Exp Pathol. 2014;7(7):4345-9.

14. Shahwan MJ, Khattab AH, Khattab MH, Jairoun AA. Association between abnormal serum hepatic enzymes, lipid levels and glycemic control in patients with type 2 diabetes mellitus. Obesity Medicine. 2019;16.

15. Saligram S, Williams EJ, Masding MG. Raised liver enzymes in newly diagnosed type 2 diabetes are associated with weight and lipids, but not glycemic control. Indian J Endocrinol Metab. 2012;16:1012-4.

16. Inayatillah B. Pengaruh ekstrak daun ketapang (Terminalia catappa L.) terhadap perbaikan kerusakan hepatosit serta kadar SGOT dan SGPT mencit (Mus musculus) diabetik [Skripsi]. Surabaya: Universitas Airlangga; 2016. 